Ruth Ann Strickland. (1995). "Sexual Harassment: A Legal Perspective for Public Administrators." Public Personnel Management 24 (Winter 1995, no. 4): 493-513. (ISSN: 0091-0260) Published by the International Public Management Association for Human Resources (IPMA-HR). The version of record can be obtained from: www.ipma-hr.org.

\title{
Sexual Harassment: A Legal Perspective for Public Administrators Ruth Ann Strickland
}

\begin{abstract}
Since the Clarence Thomas-Anita Hill hearings, there has been a heightened awareness in the U.S. of sexual harassment in the workplace. Recent case law has given men and women more protections against sexual harassment. At the same time, the liability of employers for acts of harassment in the public and private sector has increased. The purpose of this article is to discuss the issue of sexual harassment from a public administrator's viewpoint. Various types of sexual harassment are identified and preventive and remedial measures are provided.
\end{abstract}

\section{ARTICLE}

\section{Estimating the Scope of Sexual Harassment}

Surveys administered as early as 1979 indicated that numerous women in state employment were affected by sexual harassment, with as many as 59 percent of female employees in the state of Illinois reporting a direct experience with sexual harassment. In a random survey of female state employees in Florida, 46 percent claimed that they had received unwanted sexual attention from male co-workers in their present employment which caused them to feel threatened or humiliated.(1) In an examination of Alabama, Arizona, Texas, Utah and Wisconsin, women experienced all forms of sexual harassment more than men. Of high-level female public administrators in these five states, six to sixteen percent experienced unwelcome sexual advances; eleven to 24 percent experienced requests for sexual favors; fourteen to 36 percent experienced offensive physical contact and 33 to 60 percent experienced some offensive verbal behavior.(2) One estimate held that as many as one-third of women in educational institutions had experienced some kind of harassment.(3)

In 1980 the U.S Merit Systems Protection Board found that four out of ten women in a 10,648 sample had been sexually harassed during the previous 24 months. When this study was updated in 1988, the numbers reflected an uncanny resemblance to those in 1980-42 percent of all women experience some form of unwanted sexual attention.(4) 
In the private sector, the record is not much better. A 1988 survey of 160 human resources executives in the Fortune 500 companies revealed that almost all employers had at least one sexual harassment complaint in the twelve month period leading up to the survey. Representing some 3.3 million employees, 64 percent of the executives believed that the sexual harassment complaints were valid. Over 33 percent reported that their company was sued for sexual harassment during that year. A 1988 survey of 165 Long Island executives found that one in eight of their companies had been sued for sexual harassment within a year of the survey.(5) A more recent survey in 1991 taken by the American Management Association revealed that 52 percent of member companies reported one or more allegations of sexual harassment within the last five years.(6)

Polling taken during and after the Supreme Court confirmation hearings of Judge Clarence Thomas indicated a heightened awareness of sexual harassment among the general public.(7) An October 10-11, 1991 Newsweek poll found that 21 percent of women claimed that they had been harassed at work and 42 percent knew a victim of sexual harassment at work. Thirteen percent of the women polled had filed or knew someone who had filed a formal complaint of sexual harassment.(8) Another poll conducted by the New York Times/CBS News on October 9, 1991, found that four out of ten women claimed they had been the object of unwanted sexual advances or remarks from male supervisors in the workplace. Five out of ten men stated that they had said or done something that could be interpreted as sexual harassment of a female colleague.(9) Survey after survey show that somewhere between forty and seventy percent of women have experienced some form of sexual harassment.(10) As a consequence of consciousness raising, many women have begun to speak out about their experiences and discuss how they have responded to sexual harassment in the workplace.(11)

According to surveys, women report sexual harassment experiences disproportionately when compared to men.(12) Those most likely to be harassed typically occupy low power positions, have a lower socioeconomic status whether they are married or single, single or divorced and tend to be between ages 25 and 35.(13) Despite the high number of women who have reportedly experienced some form of sexual harassment, few complaints have typically been filed and some argue that the reason for this is the way definitions of harassment and dispute resolution mechanisms better fit male, rather than female, perspectives.(14)

\section{EEOC Policy at the State and Federal Levels}

Equal employment opportunity policy and sexual harassment complaints are handled by national and subnational governments. Despite the Civil Rights Act of 1964, the Equal Employment Opportunity Commission had no enforcement power prior to 1972. In 1972, the Equal Employment Opportunity Act gave the EEOC the power to file suits on behalf of persons with grievances in a workplace with fifteen or more employees. State fair employment agencies often work jointly with the EEOC in the processing of greivances.(15) States have their own laws which are designed generally to assist in federal implementation. Not all states have enacted laws forbidding sexual harassment. By 1987, 33 states established statewide sexual harassment 
policies.(16) An additional 28 states have prohibited sex discrimination. Many of these laws do not provide for compensatory or punitive damages.

\section{Sexual Harassment Case Law}

In the first sexual harassment case, Barnes v. Train (1974), the plaintiff claimed that she was fired because she refused to participate in an "after hours" affair with her boss. The district court of the District of Columbia held that this type of discrimination was not covered by the Civil Rights Act and denied her redress.(17) By 1977, a three judge United States Court of Appeal for the District of Columbia argued in Barnes v. Costle that a woman forced to have sex to keep her job would not have been a victim "but for her womanhood," setting a precedent that sexual harassment had a legal basis for redress.(18) Years later in 1986, a case filed by Michelle Vinson, a bank employee, brought forth a landmark U.S. Supreme Court ruling on sexual harassment. The Court held that sexual harassment under Title VII of the 1964 Civil Rights Act included the creation of a hostile working environment as well as direct harm. The Court also held that the mere existence of a grievance procedure and a policy against sexual harassment did not totally protect an employer from liability, even when the victim did not invoke the procedure. It did not matter whether a victim voluntarily submitted to advances or submitted under duress as long as the sexual advances could be shown to be unwelcome.(19)

Even in the Vinson case, the Court's ruling left room for the "she brought it on herself" credo by holding that a plaintiffs "sexually provocative" speech and dress could be relevant to whether the accused alledgedly offensive conduct was actually offensive.(20) The Court did not go so far as to define degrees of hostility and how relative hostility of the environment should be evaluated.(21) (See Table 1 for a brief historical overview of sexual harassment case and statutory law.)

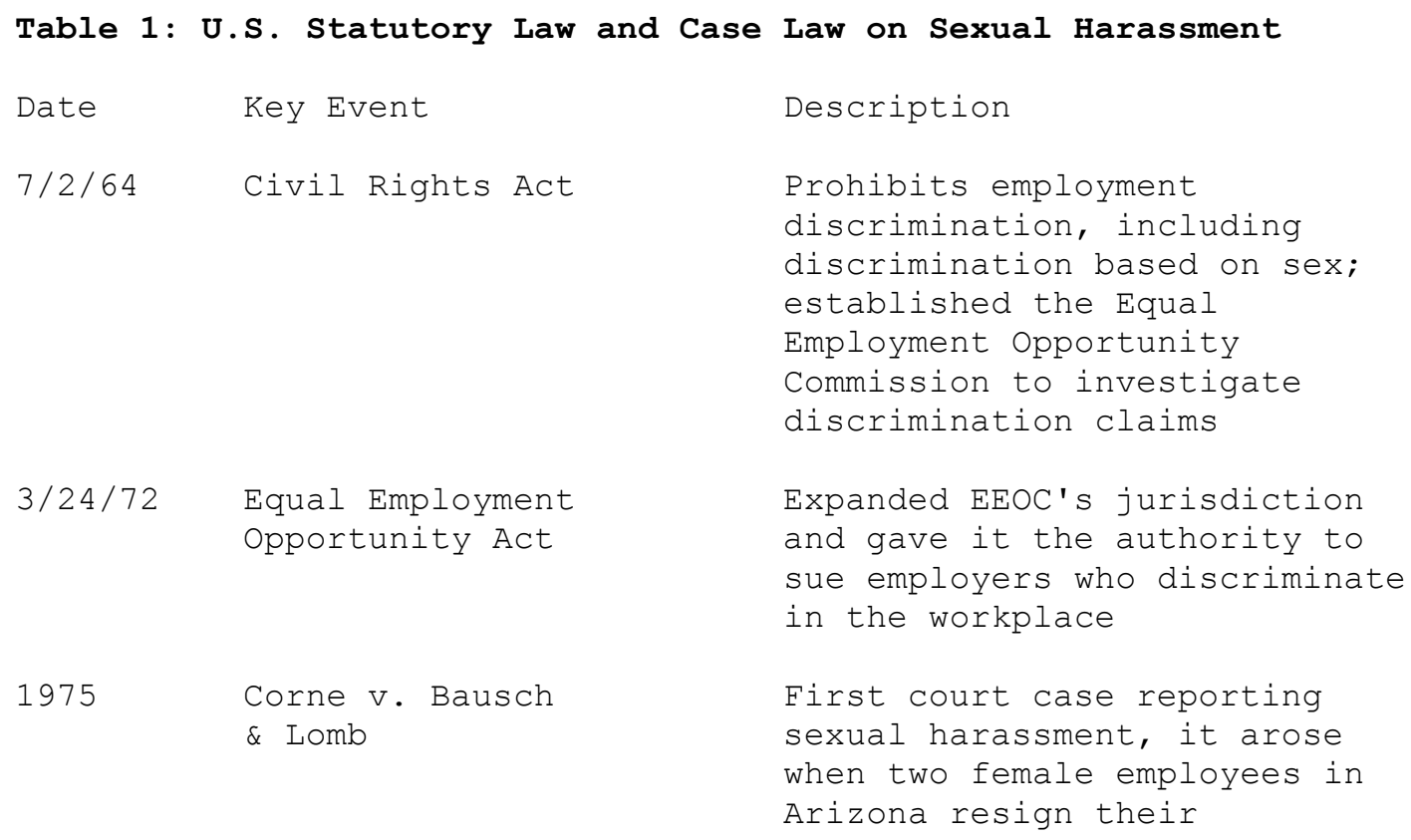


1976 Williams v. Saxbe

1977

1977

$10 / 13 / 78$

$12 / 12 / 79$

Directive defining jobs due to verbal and unwanted physical advances from their supervisor; the supervisor's advances toward the women were ruled as unrelated to employment and not actionable under Title VII

A federal district court held that there was a connection between a supervisor's conduct and a victim's employment status; first sexual harassment suit to succeed in federal district court

D.C. Circuit Court of Appeals held that Title VII of the Civil Rights Act protected women from sexual harassment in the workplace if it adversely affected job condition

Third circuit federal court found that Service Electric and employers in sexual harassment suits Gas could be held liable for acts of their employees

Five Yale undergraduates filed the first sexual harassment suit under Title IX of the Education Act Amendments

Forbade discrimination in federal personnel practices

The White House Office of Personnel sexual harassment Management issued a directive to all government agencies which defined harassment and condemned it

The regulations as formulated by the EEOC held that:

"Unwelcome sexual advances requests for sexual favors, and other verbal or physical conduct of a sexual nature constitute sexual harassment when: (1) submission to such conduct is made either explicitly or implicitly a term or condition of an 
1981

1983 Joyner v. AAA Cooper
transportation

1986

1986

Nelson $V$. Reisher

CA-4, 88-1 133 individual's employment; (2)

submission to or rejection of such conduct by an individual is used as the basis for employment decisions...or (3) such conduct has the purpose or effect unreasonably interfering with an individual's work performance or creating an intimidating, hostile or offensive working environment."

D.C. Circuit Court recognized harm created by sexual harassment vis-a-vis a hostile work environment

A. District Court ruled in favor of a male employee who claimed that unwelcome homosexual advances and unsolicited sexual harassment resulted in layoff and the employer's decision not to recall him when the position became available

Meritor Saving's Bank $v$.
Vinson

Supreme Court held that sexual harassment by a supervisor was sex discrimination under Title VII of the Civil Rights Act; the creation of a hostile working environment equaled harassment even if no economic harm was involved

Sixth Circuit held that pinups of naked women and crude sexual remarks did not create a hostile work environment in a male dominated workplace

A D.C. court upheld a sexual harassment claim which used evidence of sexual conduct aimed at co-workers to prove her claim; even a plaintiff who is not a victim of harassment directly may have a valid Title VII claim if forced to work in an offensive working environment

A male plaintiff, who claimed sexual harassment from female co-workers prevailed and was awarded $\$ 1500$ 


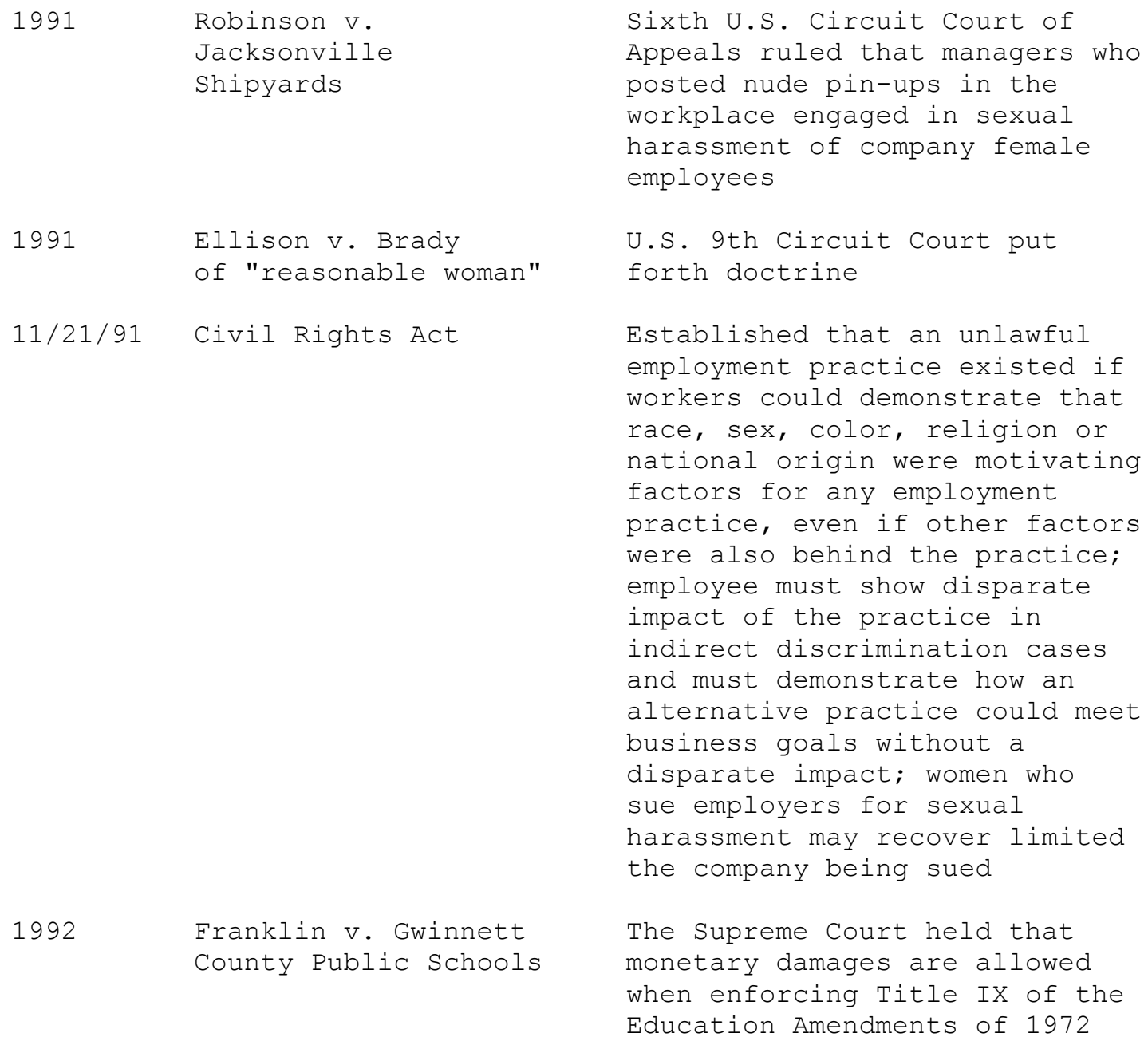

SOURCES: Congressional Quarterly Almanac. 1991. "1991 Civil Rights Law Provisions;" Mezey, 1992: 166-183; Harbrecht, 1991; Tong 1984: 65-87; Dee 1992: 44-45; Woerner and Oswald 1990: 791-792; Simon 1991; Margenson, 1989; Maschke, 1989; Koen, Jr. 1990: 9495; Forell, 1993; Whicker and Strickland, 1993.

\section{Sexual Harassment from a Public Administrator's Viewpoint}

It is extremely important for public administrators to sensitize themselves and their co-workers to sexual harassment in the workplace. Sexual harassment in the workplace has an emotional and possibly physical impact on its victims. Often worker morale and productivity decline while absenteeism increases. When a case goes to court, valuable resources are expended on attorney fees, victim fees, back pay, compensatory damages and punitive damages.(22) To combat all the costs associated with sexual harassment, public agencies must use case and statutory law to define and identify sexual harassment and must also develop prevention policies. 
There are problems involved in defining and identifying sexual harassment, since it may take many and varied forms. Numerous professional groups have been active in developing preventive measures and sexual harassment policies. This article examines the problems encountered in defining and identifying sexual harassment in the public sector. In addition, some preventive and remedial measures public administrators may take to minimize agency or employer liability in case of a sexual harassment complaint are suggested.

\section{Defining and Identifying Sexual Harassment: Setting Policy}

For the legal definitions of sexual harassment, see Table 1. To enable identification of sexual harassment and to more clearly "know it when you see it" in the workplace, there are several categories typically used to illustrate the different forms harassment may take. These are: (1) unwanted sexual advances, (2) creating a hostile environment, (3) consensual relationships that soured, (4) employee harassment of non-employees, (5) harassment of employees by nonemployees (6) female harassing male co-worker, (7) same-sex harassment, (8) unwanted physical contact and (9) quid pro quo.(23) Preventing sexual harassment may depend on the employer's ability to identify these different types and specify preventive measures that deal with the problems each type presents.

Unwanted Sexual Advances: When two people work closely together, it often is the case that attractions develop. Unfortunately for the lovesick, the attraction may be one-sided. Even more destructive, a supervisor or manager may use their power position to impose their sexual attraction on a co-worker. "Unwanted sexual advances" is the type of sexual harassment that results in pursuit--calling the victim at home after hours, constantly asking the pursued for a date, sending unsolicited gifts and letters and generally smothering the victim with unwanted attention. In recent years, some unwanted sexual advances in the workplace have turned into "stalking" the victim and when the victim refused to return the affections of a co-worker, violence has resulted. This type of fixation is the easiest to document but even so some employers have been reluctant to discipline an otherwise valuable and well-behaved employee.

Defining unwelcome sexual advances in the workplace based on the "reasonable person" standard often creates uncertainty. Should the definition of unwelcome be determined by the reasonable person of the same gender or should unwelcome be defined from a gender neutral reasonable person's perspective? In reality, we know that men and women define "unwelcome sexual advances" differently. Studies illustrate that a neutral standard can not encompass the diverse views held by men and women on what is reasonable regarding sexual conduct. For example, in a survey of Los Angeles County (1980-1981), 67 percent of men polled claimed they would be flattered by a proposition made by a woman at work whereas only 17 percent of women claimed they would be flattered if a man propositioned them at work.(24) In another survey, when asked if a man who eyed a woman's body up and down was sexual harassment, 24 percent of women believed it was while only nine percent of men did. Still a more recent 1986 poll taken by Time indicated that majorities of men and women do agree that sexual harassment occurs when a supervisor makes remarks to women that carry sexual meanings, when a supervisor puts his arm at a woman's back or pats her shoulder, when a supervisor tells sexual 
jokes, pressures a woman to go out with him or requests a woman to have sex with him.(25) To deal with possible gender differences on defining unwanted sexual advances, some federal courts have adopted a "reasonable woman" standard. Still the U.S. Supreme Court has not decided what standard should be applied when determining unwelcomeness.(26)

Creating a Hostile Environment: The "hostile environment" type of harassment is newer and in some ways harder to identify and rectify. In the Meritor case (discussed earlier and in Table 1), the courts must not only remedy a result, i.e. a firing or a promotion lost due to sexual harassment, but they must also address the psychological aspects of the workplace. The Meritor case holds that conduct of a sexual nature that is so severe as to upset the employee psychologically is also sexual harassment. In such a case, the employee must demonstrate that the sexual conduct impaired her ability to work effectively or significantly affected her psychological well-being.(27)

What constitutes a hostile environment? It may include any sexual conduct or innuendo that creates an offensive environment such as: telling sexual jokes, frequent use of vulgar language, making sexual remarks, displaying sexually graphic pictures, spreading false stories about a plaintiff's sexual contacts with the accused, making lewd remarks, engaging in name calling, sending sexually provocative messages on electronic mail, leaving obscene messages on office answering machines and X-rated software prominently displayed in office computers. One ruling, Broderick v. Ruder 46 FEP Cases 1272 (D. D.C. 1988), received much attention because a woman who was not a direct victim of sexual harassment used evidence to show that unwanted sexual conduct aimed at other co-workers created a hostile environment. So even a plaintiff, who is not directly sexually harassed but works in a pervasively hostile atmosphere created by unwanted sexual advancement directed towards co-workers, can have a valid claim of sexual harassment under Title VII.(28)

Still there have been disputes on what constitutes a hostile environment and this is again complicated by conflicting standards--reasonable person vs. reasonable man vs. reasonable woman. For example, the Sixth Circuit court held in Rabidue v. Osceola Refining Company (1986) that a reasonable person would not find pinups of naked women accompanied by frequently crude sexual remarks hostile. In essence, this court ruled that the reasonable male would not find this offensive and if women wanted to work in traditionally male occupations, they would have to acclimate themselves to the male work environment.(29)

Yet in 1991, a District Court judge in Florida held the pinups of nude females did indeed create a hostile work environment. Judge Howell Melton in his 98 page opinion wrote in the Jacksonville Shipyards case that the boys' club environment created by pinups of naked women created an environment destructive to equality in the workplace.(30) A U.S. Court of Appeals judge in the Ninth Circuit held that sexual harassment has to be judged from the reasonable woman's perspective because conduct that may not offend men may be objectionable to women. Further, Judge Robert R. Beezer in his opinion with Judge Alex Kozinski argued that since women represent disproportionately rape and sexual assault victims, they have a greater incentive to be concerned about sexual conduct. Men, who are less frequent victims of these crimes, may view sexual behavior through different perceptual lenses--not realizing that certain sexual conduct may make women feel distinctly uncomfortable.(31) Another case brewing at the state level, 
Miller v. Bloomington Hooters, Inc. EM 93-00672 (Diet. C. Hennepin Co.), addresses the issue of whether the policy of Hooters restaurant requiring waitresses to wear sexually provocative uniforms created a sexually charged atmosphere which resulted in harassment from managers of the restaurant and customers.(32)

The dispute over the Rabidue decision was settled in the U.S. Supreme Court case, Harris v. Forklift Systems, Inc., which asked whether a woman has to demonstrate that she suffered severe psychological injury to substantiate a sexual harassment claim.(33) The unanimous opinion issued by the Supreme Court in the Harris case held that a woman claiming to be harassed in the workplace does not have to prove severe psychological injury; if a "reasonable person" finds the workplace so filled with sexual innuendo and impropriety that the environment is hostile, then an employer has broken the law.(34)

Consensual Relationships That Soured: Having a relationship with a supervisor or co-worker is risky, especially if the relationship sours. Mutual attraction between two employees is not generally considered sexual harassment. Some colleges and universities have formulated rules that forbid consensual relationships between teachers and students and in effect place a negative connotation on such relationships. Sometimes what begins as consensual ends in a one-way, nonreciprocal relationship where one party loses interest. What begins as a consensual courtship may end and with devastating results, particularly if one of those rejected parties involved in the relationship is in a position to demote, fire or otherwise punish the other.(35) Of over 100 sexual harassment cases filed in federal court since Meritor and until 1990, 48 of 61 cases involved the employee's supervisor.(36)

Generally the courts or arbitrators look for a noticeable difference in the accused harasser's postrelationship behavior. Is the behavior noticeably unfriendly? What kind of punitive action was taken against the plaintiff and how soon did it occur after the consensual relationship ended? Did the accused harasser provide reasoning for a demotion, termination or other punitive action? Also, there is the problem of defining what "consensual" means, particularly in relationships between "unequals" where one employee has supervisory power over another.

Harassment of Non-Employees by Employees: Most workplaces involve not only contact with your office mates but also contact with customers, clients, and outsiders from other work environments. Various correctional facilities, for example, have come under sharp scrutiny and criticism recently for allegations that prison guards have made lewd comments to female inmates or have asked female inmates to engage in sexual acts with them in exchange for special privileges or treatment. In other public agencies, types of grievances may arise where: a worker makes lewd remarks to a citizen who seeks information or service from the agency; an employee tries to seduce the boss's daughter and an employee tells sexual jokes to clients.(37)

Harassment of Employees by Non-Employees: In most sexual harassment claims, employees allege that a supervisor harassed them. However, recent federal court rulings may open employers to another kind of complaint--harassment of employees by non-employees. In Power v. Las Vegas Hilton Corp. (1992), a U.S. District Court upheld an allegation made by a female blackjack dealer who claimed she was fired because she complained about sexual remarks made to her by customers of the casino. The casino argued that out of the thousands of customers in 
direct contact with the plaintiff, only two had made remarks and these were not sufficiently severe or pervasive to warrant the hostile environment label. The court ruled in this instance that the failure of the employer to remedy or prevent a hostile work environment resulted in liability.(38) Recent claims by former waitresses of the Hooters restaurant chain also illustrate the problem of harassment from non-employees.(39) In public agencies, this form of harassment may occur if clients tell lewd jokes that offend public employees and there is no agency policy to deal with such behavior.

Female Harassing Male Co-Worker: One recent dispute involving a male former manager at a spa manufacturing company and his former female boss was resolved by a Superior Court jury verdict in the man's favor of more than $\$ 1$ million. The man claimed that his female superior had harassed him daily on the job for six years. Although other men have successfully won damage awards in sexual harassment suits, experts have not heard of any man winning such a large award (which maybe attributed to California's policy not to cap punitive damage awards) The case focused attention on a problem that may have been overlooked due to the intense focus on male-on-female harassment. As the attorney for the male manager remarked, men too are entitled to equal opportunity and freedom from the harms that sexual harassment inflicts.(40)

In 1992, the U.S. EEOC reported that 968 (or nine percent) of 10,577 sexual harassment claims were filed by men; in 1991, filings by men were 514 ( 7.5 percent) of 6,886. The figures do not indicate whether the complaints were against men or women but they do indicate that men are victims of sexual harassment and are typically even more reluctant to come forward than women.

Most reports of sexual harassment involve male harassment of female co-workers. However, as surveys indicate men experience harassment too. As women gain more power and supervisory positions, the probability of females harassing males will increase.(41)

Same Sex Harassment: It is possible that persons of the same sex will develop attractions and possibly use their power positions to obtain sexual favors from an employee. Reports of same sex harassment are rare. Although Title VII does not specifically prohibit discrimination on the basis of sexual preference, it does prohibit sexual harassment between employers of the same sex as well as when both sexes are involved.(42) In Joyner v. AAA Cooper Transportation 597 F. Supp. (1983), a case of homosexual sexual harassment was alleged. In this case, the employee apparently was laid off and was not recalled when the position opened up again because the employee refused the homosexual advances made by his manager. To establish a prima facie case, the employee had to: belong to a protected group; experience unwelcome sexual harassment, not experienced by members of the opposite sex; request to return to work and be denied return, although qualified and when the position re-opened, the job was filled by someone else with the same qualifications despite the plaintiff's desire to return to the job.(43) In this case, the District Court ruled in the plaintiff's favor and ordered reinstatement with back pay.

Unwanted Physical Contact: "Look but don't touch" is generally the rule of thumb in a society where people don't like to have their physical space invaded. In the workplace, this rule may not always be applicable, especially in a working environment where close friendships develop. Yet unwanted physical contact between employees is more likely to occur in touchy-feely environments. Various types of unwanted physical contact include kissing, hugging, pinching, 
touching, brushing up against a coworker "accidentally" and coercing someone to touch an exposed body part. One case, Dornhecker v. Malibu Grand Prix Corp. (44 FEP Cases 1604, 5th Cir. 1987), illustrated a clear example of unwanted physical contact. During a business trip, a male contract consultant employed by Malibu Grand Prix Corp. put his hands on his female coworker's hips then exposed himself by dropping his pants in front of her. He proceeded to touch her breasts and even choke her when she asked him to cease. Although on appeal the judge noted that the behavior of the contract consultant constituted sexual harassment, the company under suit was able to escape penalty because it took prompt remedial action and had a policy that terminated the working relationship between the plaintiff and her harasser for the remainder of the business trip.

Quid Pro Quo: In a quid pro quo harassment scenario, the supervisor conditions promotion and job advancement or even employment on sexual favors--blatantly retaliating against an employee that does not respond to sexual advances. The quid pro quo type of harassment is often easier to remedy because the courts can remedy loss of job or denial of promotion more easily than they can put a value on the "hostile work environment."(44) Although easier to remedy, it is not always easy to identify because direct evidence of a supervisor saying "sleep with me or you're fired" may not exist. This may result in a "he says, she says" scenario. To prove that quid pro quo harassment occurred, the employee must: belong to a protected group; be subject to unwelcome sexual harassment; complain that the harassment was based upon sex and show that a tangible job benefit was lost due to refusal reaction to acquiesce to a supervisor's sexual demands.(45) The supervisor's actions on behalf of the employer in making employment decisions can be imputed to the employer under the principle of respondeat superior.(46)

\section{Sexual Harassment: Preventive Measures}

\section{To prevent sexual harassment, government agencies should:}

(1) Be familiar with the varying forms of sexual harassment that can take place (particularly quid pro quo and hostile environment).

(2) Use EEOC guidelines and case law to clearly define sexual harassment and explain the various types to employees.(47)

(3) Establish a written sexual harassment policy.

(4) Communicate the policy to all employees on a regular basis by:

(a) having training sessions for current employees to ensure their

familiarity with the policy; and

(b) acquainting new arrivals by providing comprehensive training on the 
workings of the policy.(48)

(5) Strongly denounce sexual harassment and confirm that it will not be tolerated and connect sexual harassment violations to disciplinary remedies.(49)

(6) Inform all employees of their legal rights to complain about sexual harassment under Title VII of the Civil Rights Act of 1964 by:

(a) educating employees on how to recognize and confront harassment and

(b) setting up workshops for women only to promote openness and frank

discussion.(50)

(7) Do not ignore complaints just because they are not formally filed.

(8) Do not ignore complaints because they allegedly happened several years ago.

(9) Do not try to convince an employee not to complain or to defend the offensive behavior as "only joking."

(10) Do not dismiss an employee who complains as a way to remove potential problems for the agency.

(11) Do not put off taking action simply because an allegedly harassed employee asks that no action be taken.(51)

Although not addressed in the prevention guidelines here, dating in the workplace should be handled with care. Unwritten and unspoken codes often prevail at public universities where professor-student relationships sometimes develop. Many universities do not condone such dating but neither do they prohibit it, thereby allowing potentially exploitative relationships to grow and fester. Of those that do have dating policies, questions arise over how to enforce them and students often state that they are adults and should be able to pursue any romantic involvement of their choosing. Similarly in public agencies where supervisors may choose to date a co-employee or subordinate, the possibility exists that a consensual relationship may become non-consensual.

Public agencies can formulate written policies that govern supervisor-subordinate dating and coemployee dating and they can survive legal challenges claiming violation of privacy as long as they are justified by a "compelling state interest." Most likely a policy that forbade supervisorsubordinate dating would survive such a challenge on the grounds that it protects the agency against harassment claims and possibly prevents favoritism based on the dating relationship.(52)

\section{Sexual Harassment: Remedial Measures}




\section{Agencies should have the following remedial measures in place:}

(1) Establish investigatory procedures to ensure that claims are resolved quickly by:

(a) designating an investigator whose demeanor is credible;

(b) retrieving and reviewing pertinent documents/documentation;

(c) identifying and interviewing possible witnesses;

(d) asking questions of witnesses such as:

--what happened according to the complainant?

--how did the complainant respond?

--were the complainant's work functions affected?

--how was the complainant affected otherwise?

--who else witnessed the incident(s)?

--was the incident isolated or part of a Pattern?

--is there any physical evidence of the incident(s) or

documentation, such as a diary?(53)

--what happened according to all

possible witnesses?

(2) Ensure no retaliation against the complainant, no matter what the outcome of the findings.

(3) Before making a determination inform the accused and give him/her a chance to respond.

(4) Present the findings in a confidential report.

(5) Circulate the report to relevant supervisors but require that no copies be made and that they return it promptly.(54)

(6) Have sanctions in place for harassment and explain them to employees.

(7) Establish a procedure for dealing with sexual harassment claims that protects the victim by:

(a) having procedures in place that protect victim privacy and 
confidentality;

(b) creating grievance channels that allow the victim to bypass those involved in the harassment complaint and

(c) letting potential victims know that complaints will receive prompt attention and that disciplinary action will be swift.(55)

(8) Provide follow-up care to victims of harassment by:

(a) emphasizing the agency's policy of condemning harassment;

(b) making sure that harassment has stopped and

(c) assuring the victim and others that disciplinary action was taken

(9) Evaluate the awareness and compliance with anti-harassment policies in the agency periodically by:

(a) using written questionnaires and

(b) using exit interviews.(56)

\section{Misconceptions About Sexual Harassment}

Following the Anita Hill-Clarence Thomas hearings, many men voiced fears that sexual harassment might include almost any kind of male-female interaction, even a compliment on a woman's appearance or asking another employee what their weekend was like. In general, there was fear that good-humored joking or everyday exchanges over coffee might be misinterpreted or misunderstood and that office interaction would turn into walking on eggshells, where every word and action would have to be weighed with extreme care.(57) Generally this view of what constitutes sexual harassment is a misconception. Under the law, these fears have little basis. Sexual harassment does not apply to everyday normal, friendly interaction or even mild flirtation, as long as no reasonable woman (person) is offended. Common sense and a sensitivity to other's reactions to what is said are necessary in any collegial work environment. Sexual harassment case law does not prevent both sexes from enjoying each other's company in the workplace.(58)

\section{Notes}

(1.) Douglas I. McIntyre and James C. Renick, "Protecting Public Employees and Employers from Sexual Harassment," Public Personnel Management 11 (1982): 282-292. 
(2.) Rita Mae Kelly and Phoebe Morgan Stambaugh, "Sexual Harassment in the States," in Women and Men of the States Public Administrators at the State Level, ed. Mary Ellen Guy (New York: M.E. Sharpe, 1992).

(3.) Sylvia Kenig and John Ryan, "Sex Differences in Levels of Tolerance and Attribution of Blame for Sexual Harassment on a University Campus," Sex Roles 15 (1986): 535-549.

(4.) U.S. Merit Systems Protection Board, Sexual Harassment in the Federal Government: Is It a Problem? (Washington, D.C.: GPO, 1981); U.S. Merit Systems Protection Board, Sexual Harassment in the Federal Government: An a Update (Washington, D.C. GPO, 1988).

(5.) Donald Bacon, "See You In Court," Nation's Business 77 duly 1989): 17-18.

(6.) Ellen J. Wagner, Sexual Harassment in the Workplace; How to Prevent, Investigate, and Resolve Problems in Your Organization (New York: American Management Association 1992).

(7.) Sheldon J. Stark, "Sexual Harassment in the Workplace: Lessons from the Thomas-Hill Hearings," Trial (May 1992): 116-122.

(8.) Barbara Kantrowitz, "Striking an Nerve," Newsweek 153 (21 October 1991): 34;38.

(9.) Elizabeth Kolbert, "Sexual Harassment at Work Is Pervasive," New York Times, 11 October 1991, A1.

(10.) Tamar Lewin, "A Case Study of Sexual Harassment," New York Times, 1 October 1991 A18.

(11.) Amber Coverdale Sumrall and Dena Taylor, Sexual Harassment: Women Speak Out. (Freedom, California: The Crossing Press, 1992).

(12.) Donald E. Maypole, "Sexual Harassment of Social Workers at Work: Injustice Within?," Social Work 31 (January-February 1986): 29-34.

(13.) Brian S. Moskal, "Sexual Harassment '80s Industry Week 238 (3 July 1989): 22-24; David E. Terpstra, "Who Gets Sexually Harassed?," Personnel Administrator (March 1989): 84-85; Terri C. Fain and Douglas L. Anderton, "Sexual Harassment: Organizational Context and Diffuse Status," Sex Roles 17 (1987): 291-311, Edward Lafontaine and Leslie Tredeau, "The Frequency Sources, and Correlates of Sexual Harassment Among Women in Traditional Male Occupations Sex Roles 15 (1986): 433-442; Barbara A. Gutek and Bruce Marasch, "Sex Rations, Sex-Role Spillover, and Sexual Harassment of Women at Work, "Journal of Social Issues 38 (1982): 55-74.

(14.) Klein Associates, "How Employees Perceive Sexual Harassment," Harvard Business Review 70 (March-April 1992): 23; Stephanie Riger, "Gender Dilemmas in Sexual Harassment: Policies and Procedures," American Psychologist 46 (May 1991); 497-505. 
(15.) Charles S. Clark, "Sexual Harassment," CQ Researcher (9 August 1991); 537-360.

(16.) Kelly and Stambaugh, 1992.

(17.) Dail A. Neugarten, "Sexual Harassment in Public Employment," in Public Personnel Administration; Problems and Prospects, ed. Steven W. Hays and Richard C. Kearney (Englewood Cliffs N.J.; Prentice-Hall 1990), William L. Woerner and Sharon L. Oswald, "Sexual Harassment in the Workplace: A View Through the Eyes of the Courts," Labor Law Journal (November 1990);

(18.) Stark, 1992.

(19.) Robert K. Robinson, Billie M. Allen, Geralyn McClure Franklin, and David L. Duhon, "Sexual Harassment in the Workplace: A Review of the Legal Rights and Responsibilities of All Parties," Public Personnel Management 22 (Spring 1993): 123-135; Joan Hoff, Law, Gender, and Injustice: A Legal History of U.S. Women (New York and London: New York University Press, 1991), Robert C. Ford and Frank McLaughlin, "Sexual Harassment at Work: What is the Problem," Akron Business and Economic Review 40 (Winter 1989): 79-92; Leslie Friedman Goldstein, The Constitutional Rights of Women: Cases in Law and Social Change (Madison: University of Wisconsin Pres, 1989).

(20.) Neugarten, 1990; Deborah L. Rhode, Justice and Gender: Sex Discrimination and the Law (Cambridge: Harvard University Press, 1989).

(21.) E. Clayton Hipp, Jr., "Now You See It, Now You Don't: The "Hostile Work Environment" After Meritor," American Business Law Journal 26 (Summer 1988): 339-361.

(22.) Susan Crawford, "A Wink Here, A Leer There: It's Costly, "New York Times, 28 March 1993 17; Dorothy Rabinowitz, "A Cautionary Tale: The High Price of a Wall Street Office Romance," New York (8 January 1990): 35-40; Catherine Breslin and Michele Morris, "Please Leave Me Alone," Working Woman 13 (December 1988): 74-78, Maria Barbuto, "Sexual Harassment Seen As Unproductive in the Workplace," Middlesex News, 7 December 1987.

(23.) Stephen A. Ploscowe and David W. Garland "Scope of Harassment Liability Expands, "The National Law Journal 15 (8 February 1993): 23; 26-27; Joel Friedman, Marcia Mobilia Boumil, and Barbara Ewert Taylor, Sexual Harassment: What It Is, What It Isn't What It Does to You and What You Can Do About It (Deerfield Beach, Florida: Health Communications, Inc., 1992; William A. Nowlin, "Sexual Harassment in the Workplace: How Arbitrators Rule," The Arbitration Journal 43 (December 1998): 31-40.

(24.) Barbara A. Gutek, Sex and the Workplace: The Impact of Sexual Behavior and Harassment on Women, Men and Organizations (San Francisco: Jossey-Bass, 1985).

(25.) Clark, 1991.

(26.) Caroline Forrell, "Sexual and Racial Harassment," Trial 29 (March 1993): 70.72; 74-76. 
(27.) Friedman et. al., 1992.

(28.) Michele Galen, Zachary Schiller, Joan O'C. Hamilton, and Keith H. Hammonds "Ending Sexual Harassment: Business Is Getting the Message," Business Week (March-April 1991) 98100; Clifford M. Koen, Jr., "Sexual Harassment Claims Stem from a Hostile Work Environment," Personnel Journal 69 (August 1990): 88-89; 92; 94-95; 97-99.

(29.) Forrell, 1993.

(30.) Susan Tifft, "A Setback for Pinups at Work," Time 137 (4 February 1991): 61.

(31.) Galen et.al., 1991, Robert T. Gray, "How to Deal With Sexual Harassment," Nation's Business 79 (December 1991) 28;30.

(32.) Andrew Blum, "Assumption of Risk Tested in Hooters Suit," The National Law Journal 15 (24 May 1993): 7.

(33.) Joan Biskupic, "Questions of Rights Come Before the Supreme Court," Washington Post National Weekly Edition, 11-17 October 1993, 31-32; John W. Morre, "The Case of the Hanging Curve Ball," National Journal 25 (12 June 1993): 1434.

(34.) "Court Expands Sex-Harassment Protection," Winston-Salem Journal, 10 November 1993, $1 ; 4$.

(35.) Donna M. Stringer, Helen Remick, Jan Salisbury and Angela B. Ginorio "The Power and Reasons Behind Sexual Harassment: An Employer's Guide to Solutions," Public Personnel Management 19 (Spring 1990): 43-52.

(36.) Koen, 1990.

(37.) Lynn Hecht Schafran, "Sexual Harassment: An Ounce of Prevention Trial (January 1994): 20-21.

(38.) Ploscowe and Garland, 1993.

(39.) Michele Ingrassia, "Abused and Confused," Newsweek 122 (25 October 1993): 57-58.

(40.) "Man Wins Sex-Harassment Suit Against Woman," New York Times, 21 May 1993): A21(N).

(41.) Angela M. Bullard and Deil S. Wright, "Circumventing the Glass Ceiling: Women Executives in American State Governments," Public Administration Review 53 (May/June 1993): 189-202.

(42.) Wagner, 1992. 
(43.) Stacey J. Garvin, "Employer Liability for Sexual Harassment," HR Magazine 36 (June 1991): 101; 103-104; 106-107.

(44.) Friedman et al., 1992

(45.) Garvin, 1991

(46.) The principle, respondent superior, literally means that the master is responsible for the acts of the servant and in this case, the employer is responsible for the acts of the employee.

(47.) Brenda T. Acken, Kent St. Pierre, and Peter Veglahn, "Limiting Sexual Harassment Liability," Journal of Accountancy 171 (June 1991): 4244; 4647.

(48.) Koen, 1990; Paul J. Champagne, "Auditing Sexual Harassment" Personnel Journal 68 (June 1989): 124; 126; 128; 131-132; 139.

(49.) Jeri Spann, "Dealing Effectively With Sexual Harassment: Some Practical Lessons From One City's Experience," Public Personnel Management 19 (Spring 1990): 53-69.

(50.) Azy Barak, "Combatting Sexual Harassment," The American Psychologist 47 (June 1992): 818-819, Robert K. McCalla, "Stopping Sexual Harassment Before It Begins," Management Review (April 1991): 44-46, Donald H. Weiss, "The Principle Ingredients of a Sexual Harassment Policy," Nation's Business 79 (December 1991): 31.

(51.) "Effective Policies for Prevention and Investigation HR Focus (February 1992): 11.

(52.) Kathleen M. Hallinan, "Invasion of Privacy or Protection Against Sexual Harassment: CoEmployee Dating and Employer Liability," Columbia Journal of Law and Social Problems 26 (Spring 1993): 435-546.

(53.) J.H. Foegen, "The Double Jeopardy of Sexual Harassment," Business and Society Review (Summer 1992): 31-35.

(54.) Galen et.al., 1991; Cheryl Blackwell Bryson, "The Internal Sexual Harassment Investigation: Self Evaluation Without Self-Incrimination," Employee Relations Labor Journal 15 (Spring 1990): 551-559.

(55.) Foegen, 1992.

(56.) Susan M. Benton-Powers, "Sexual Harassment: Civil Rights Act Increases Liability," HR Focus (February 1992): 10, Juliana Lightle and Elizabeth H. Doucet, Sexual Harassment in the Workplace: A Guide to Prevention (Los Altos California: Crisp Publications, Inc., 1992); Kelly Flynn, "Preventive Medicine for Sexual Harassment," Personnel 68 (March 1991): 17; James G. Frierson, "Reduce the Costs of Sexual Harassment," Personnel Journal 68 (November 1989): 79 85; William L. Kandel, "Sexual Harassment: Persostent, Prevalent, But Preventable," Employee Relations Labor Journal 14 (Winter 1988): 439-451. 
(57.) Foegen, 1992.

(58.) Wagner, 1992

\section{References}

Acken, Brenda T., Kent St. Pierre, and Peter Veglahn. "Limiting Sexual Harassment Liability." Journal of Accountancy 171 (June 1991): 42-44; 46-47.

Bacon, Donald C. "See You In Court." Nation's Business 77 (July 1989): 17-18; 20; 22; 24; 26; 28.

Barak, Azy. "Combatting Sexual Harassment." The American Psychologist 47 (June 1992): 818819.

Barbuto, Maria. "Sexual Harassment Seen As Unproductive in the Workplace." Middlesex News, 7 December 1987.

Benton-Powers, Susan M. "Sexual Harassment: Civil Rights Act Increases Liability." HR Focus (February 1992): 10.

Biskupic, Joan. 1993. "Questions of Rights Come Before the Supreme Court." Washington Post National Weekly Edition, 11-17 October 1993, 31-32.

Blum, Andrew. "Assumption of Risk Tested in Hooters Suit." The National Law Journal 15 (24 May 1993): 7.

Breslin, Catherine, and Michele Morris. "Please Leave Me Alone." Working Woman 13 (December 1988): 74-78; 80; 82.

Bryson, Cheryl Blackwell. "The Internal Sexual Harassment Investigation Self Evaluation Without Self-Incrimination." Employee Relations Labor Journal 15 (Spring 1990): 551-559.

Bullard, Angela M., and Deil S. Wright. "Circumventing the GlassCeiling: Women Executives in American State Governments." Public Administration Review 53 (May/June 1993): 189-202.

Champagne, Paul J. "Auditing Sexual Harassment." Personnel Journal 68 (June 1989): 124; 126; $128 ; 131-132 ; 139$.

Clark, Charles S. 1991. "Sexual Harassment." CQ Researcher (9 August 1991): 537-560.

Congressional Quarterly Almanac. "1991 Civil Rights Law Provisions." 47 (1991): 258-261.

"Court Expands Sex-Harassment Protection." Winston-Salem Journal, 10 November 1993: 1; 4. 
Crawford, Susan. "A Wink Here, A Leer There: It's Costly." New York Times, 28 March 1993, 17.

Dee, Catherine. The Women's 1992 Voting Guide. Berkeley: EarthWorks Press, 1992.

Dillin, John. "Women Marking Slow, Steady Gains in US Politics." Christian Science Monitor, 18 July 1991, 9.

"Effective Policies for Prevention and Investigation." HR Focus (February 1992): 11.

Fain, Terri C., and Douglas L. Anderton. "Sexual Harassment: Organizational Context and Diffuse Status." Sex Roles 17 (1987): 291-311.

Flynn, Kelly. "Preventive Medicine for Sexual Harassment." Personnel 68 (March 1991): 17.

Foegen, J.H. "The Double Jeopardy of Sexual Harassment." Business and Society Review (Summer 1992): 31-35.

Ford, Robert C., and Frank McLaughlin. "Sexual Harassment at Work: What is the Problem?" Akron Business and Economic Review 40 (Winter 1989): 79-92.

Forell, Caroline. "Sexual and Racial Harassment." Trial 29 (March 1993): 70; 72; 74-76.

Friedman, Joel, Marcia Mobilia Boumil, and Barbara Ewert Taylor. Sexual Harassment: What It Is, What It Isn't, What It Does to You and What You Can Do About It. Deerfield Beach, Florida: Health Communications, Inc., 1992.

Frierson, James G. "Reduce the Costs of Sexual Harassment." Personnel Journal 68 (November 1989): 79-85.

Galen, Michele, Zachary Schiller, Joan O'C. Hamilton, and Keith H. Hammonds. "Ending Sexual Harassment: Business Is Getting the Message." Business Week (March-April 1991): 98-100.

Garvin, Stacey J. "Employer Liability for Sexual Harassment." HR Magazine 36 (June 1991): $101 ; 103-104 ; 106-107$.

Goldstein, Leslie Friedman. The Constitutional Rights of Women: Cases in Law and Social Change. Madison: University of Wisconsin Press, 1989.

Gray, Robert T. "How to Deal With Sexual Harassment." Nation's Business 79 (December 1991): $28 ; 30$

Gutek, Barbara A., and Bruce Morasch. "Sex Rations Sex-Role Spillover, and Sexual Harassment of Women at Work." Journal of Social Issues 38 (1982): 55-74. 
Gutek, Barbara A. Sex and the Workplace: The Impact of Sexual Behavior and Harassment on Women, Men, and Organizations. San Francisco: Jossey-Bass, 1985.

Hallinan, Kathleen M. "Invasion of Privacy or Protection Against Sexual Harassment: CoEmployee Dating and Employer Liability." Columbia Journal of Law and Social Problems 26 (Spring 1993): 435-546.

Harbrecht, Douglas. "Out of the Shadows." Business Week, no. 3237 (28 October 1991): 30-35.

Hipp, Jr., E. Clayton. "Now You See It, Now You Don't: The "Hostile Work Environment" After Meritor," American Business Law Journal 26 (Summer 1988): 339-361.

Hoff, Joan. Law, Gender, and Injustice: A Legal History of U.S. women. New York and London: New York University Press, 1991.

Ingrassia, Michele. "Abused and Confused." Newsweek 122 (25 October 1993): 57-58.

Kandel, William L. "Sexual Harassment: Persistent, Prevalent, But Preventable." Employee Relations Labor Journal 14 (Winter 1988): 439-451.

Kantrowitz, Barbara. "Striking a Nerve." Newsweek. 153 (21 October 1991): 34-40.

Kelly, Rita Mae, and Phoebe Morgan Stambaugh. "Sexual Harassment in the States." In Women and Men of the States: Public Administrators at the State Level. ed. Mary E. Guy, Armonk, N.Y.: M.E. Sharpe, 1992.

Kenig, Sylvia, and John Ryan. "Sex Differences in Levels of Tolerance and Attribution of Blame for Sexual Harassment on a University Campus." Sex Roles 15 (1986): 535-549.

Klein Associates. "How Employees Perceive Sexual Harassment." Harvard Business Review 70 (March-April 1992): 23.

Koen, Jr., Clifford M. "Sexual Harassment Claims Stem from a Hostile Work Environment." Personnel Journal 69 (August 1990): 88-89; 92; 94-95; 97-99.

Kolbert, Elizabeth. "Sexual Harassment at Work Is Pervasive, Survey Suggests." New York Times, 11 October 1991, A1; A18.

Lafontaine, Edward, and Leslie Tredeau. "The Frequency, Sources, and Correlates of Sexual Harassment Among Women in Traditional Male Occupations." Sex Roles 15 (1986): 433-442.

Lewin, Tamar. "A Case Study of Sexual Harassment." New York Times, 11 October 1991, A18.

Lightle, Juliana, and Elizabeth H. Doucet. Sexual Harassment in the Workplace: A Guide to Prevention. Los Altos, California: Crisp Publications, Inc., 1992. 
"Man Wins Sex-Harassment Suit Against a Woman." The New York Times, 21 May 1993, A12(N).

Maschke, Karen J. Litigation, Courts, and Women Workers. New York: Praeger, 1989.

Maypole, Donald E. "Sexual Harassment of Social Workers at Work: Injustice Within?" Social Work 31 January-February 1986): 29-34.

McCalla, Robert K. "Stopping Sexual Harassment Before It Begins." Management Review (April 1991): 44-46.

McIntyre, Douglas I., and James C. Renick. "Protecting Public Employees and Employers from Sexual Harassment." Public Personnel Management Journal 11 (1982): 282-292.

Mezey, Susan Gluck. In Pursuit of Equality: Women, Public Policy, and the Federal Courts. New York: St. Martin's Press, 1992.

Moore, W. John. "The Case of the Hanging Curve Ball." National Journal 25 (12 June 1993): 1434.

Morgenson, Gretchen. "Watch That Leer, Stifle That Joke." Forbes 143 (15 May 1989): 69-72.

Moskal, Brian S. "Sexual Harassment '80s-Style." Industry Week 238 (3 July 1989): 22-24; 27.

Nowlin, William A. "Sexual Harassment in the Workplace: How Arbitrators Rule." The Arbitration Journal 43 (December 1988): 31-40.

Nuegarten, Dail A. "Sexual Harassment in Public Employment." In Public Personnel Administration: Problems and Prospects, ed. Steven W. Hays and Richard C. Kearney. Englewood Cliffs, N.J.: Prentice-Hall, 1990.

Ploscowe, Stephen A., and David W. Garland. "Scope of Harassment Liability Expands." The National Law Journal 15 (8 February 1993): 23; 26-27.

Rabinowitz, Dorothy. "A Cautionary Tale: The High Price of a Wall Street Office Romance." New York (8 January 1990): 35-40.

Rhode, Deborah L. Justice and Gender: Sex Discrimination and the Law. Cambridge: Harvard University Press, 1990.

Riger, Stephanie. "Gender Dilemmas in Sexual Harassment: Policies and Procedures." American Psychologist 46 (May 1991): 497-505.

Robinson, Robert K., Billie M. Allen, Geralyn McClure Franklin, and David L. Duhon. "Sexual Harassment in the Workplace: A Review of the Legal Rights and Responsibilities of All Parties." Public Personnel Management 22 (Spring 1993): 123-135. 
Schafran, Lynn Hecht. "Sexual Harassment: An Ounce of Prevention." Trial (January 1994): 14; $16 ; 18 ; 20-21 ; 22-23$.

Simon, Howard A. "Ellison v. Brady: A "Reasonable Woman" Standard for Sexual Harassment." Employee Relations Labor Journal 17 (Summer 1991): 71-80.

Spann, Jeri. "Dealing Effectively With Sexual Harassment: Some Practical Lessons From One City's Experience." Public Personnel Management 19 (Spring 1990): 53-69.

Stark, Sheldon J. "Sexual Harassment in the Workplace: Lessons from the Thomas-Hill Hearings." Trial (May 1992): 116-122.

Stringer, Donna M., Helen Remick, Jan Salisbury, and Angela B. Ginorio. "The Power and Reasons Behind Sexual Harassment: An Employer's Guide to Solutions." Public Personnel Management 19 (Spring, 1990): 43-52.

Sumrall, Amber Coverdale, and Dena Taylor. Sexual Harassment: Women Speak Out. Freedom, California: The Crossing Press, 1992.

Terpstra, David E. "Who Gets Sexually Harassed?" Personnel Administrator (March 1989): 84$88 ; 111$.

Tifft, Susan. "A Setback for Pinups at Work." Time 137 (4 February 1991): 61.

Tong, Rosemarie. Women, Sex, and the Law. Totowa, N.J.: Rowman \& Allanheld, 1984.

U.S. Merit Systems Protection Board. Sexual Harassment in the Federal Government: Is It a Problem? Washington, D.C.: GPO, 1981.

U.S. Merit Systems Protection Board. Sexual Harassment in the Federal Government: An Update. Washington, D.C.: U.S. GPO, 1988.

Wagner, Ellen J. Sexual Harassment in the Workplace: How to Prevent, Investigate, and Resolve Problems in Your Organization. New York: American Management Association, 1992.

Weiss, Donald H. "The Principle Ingredients of a Sexual Harassment Policy." Nation's Business 79 (December 1991): 31.

Whicker, Marcia Lynn, and Ruth Ann Strickland. An Analysis of EEOC Sexual Harassment Filings By State, Paper presented at the Annual Midwest Political Science Association, Chicago, Il., April 1993.

Woerner, William L., and Sharon L. Oswald. "Sexual Harassment in the Workplace: A View Through the Eyes of the Courts." Labor Law Journal (November 1990): 786-793. 